\title{
FAKTOR RISIKO KEJADIAN OVERWEIGHT PADA ANAK STUNTING USIA SEKOLAH DASAR DI SEMARANG TIMUR
}

\author{
Kinanthi Mestuti H, Deny Yudi Fitranti ${ }^{*}$ \\ Program Studi Ilmu Gizi Fakultas Kedokteran Universitas Diponegoro \\ Jl.Dr.Sutomo No.18, Semarang, Telp (024) 8453708, Email : gizifk@undip.ac.id
}

\begin{abstract}
Background : Being stunted increase the risk of overweight 1,7-7,8 higher than a normal child. Adequacy of energy, fat and protein intake, low activity level, higher family income, and parental's nutrition status tend to increase overweight incident in stunted children. Meanwhile, elementary school aged children potentially become overwight through their changing feeding pattern and physical activity level.

Objective : The study aimed to determine risk fators of concurrent overweight in stunted elementary school aged children.

Method : Research design of this study was case control with age, sex, severity level of stunting matching from 4 different elementary school in Semarang Timur. Subject were 30 children in case group (overwight in stunted children) and 30 children in control group (non overwight in stunted children). Stunting determined by height/age indicator and overweight determined by body mass index/age. Energy, fat and protein intake were assesed by semiquantitative food frequency questionaire (FFQ), whereas physical activity was measured by physical activity questionaire. Family income and parental's nutritional status were collected by questionaire and antropometric measurements. The risk factors were analyzed by chi-square test.

Result : Adequacy of energy intake $(O R=9,3395 \% C I=2,85-30,6)$, adequacy of fat intake (OR=6 95\%CI=1,48$24,3)$, adequacy of protein intake $(O R=3,8295 \% C I=1,15-12,71)$, and maternal's nutritional status $(O R=4,97$ $95 \% C I=1,39-17,82)$ were risk factors of overweight in stunted elementary school aged children. Whereas physical activity level $(O R=0,8895 \% C I=0,32-2,4)$, family per capita income level $(O R=3,595 \% C I=0,65-2,67)$, and paternal nutritional status $(O R=195 \% C I=0,34-2,92)$ weren't risk factors of overweight in stunted elementary school aged children.

Conclusion : Adequacy of energy intake, adequacy of energy intake fat intake, Adequacy of energy intake protein intake and maternal's nutritional status were risk factors of overweight in stunted elementary school aged children.

Keywords : adequacy of energy intake; adequacy of fat intake; adequacy of protein intake; perental's nutritional status; overweight; stunting
\end{abstract}

\begin{abstract}
ABSTRAK
Latar belakang : Anak stunting memiliki risiko untuk menjadi overweight sebesar 1,7-7,8 kali. Kecukupan energi, protein, dan lemak berlebih, aktivitas fisik rendah, tingkat pendapatan perkapita keluarga tinggi, dan status gizi overweight pada ayah maupun ibu cenderung meningkatkan kejadian overweight pada anak stunting. Anak SD rentan menjadi overweight akibat perubahan pola makan dan aktivitas fisik pada usia tersebut.

Tujuan : Mengetahui faktor risiko kejadian overweight pada anak stunting usia sekolah dasar

Metode : Desain penelitian case control study dengan matching usia, jenis kelamin, dan derajat stunting dari 4 SD di Semarang Timur. Subjek penelitian terdiri dari 30 kelompok kasus (stunting dengan overweight) dan 30 kelompok kontrol (stunting tidak overweight). Kriteria stunting menggunakan indikator TB/U sedangkan kriteria overweight menggunakan indikator IMT/U. Asupan energi, lemak dan protein dihitung dengan food frequency questionaire (FFQ) semi kuantitatif dan aktivitas fisik menggunakan kuesioner aktivitas fisik. Tingkat pendapatan perkapita keluarga dan status gizi ayah serta status gizi ibu diperoleh melalui form kuesioner dan pengukuran antropometri. Analisa faktor risiko menggunakan uji Chi Square.

Hasil : Faktor risiko kejadian overweight pada anak stunting adalah kecukupan energi (OR=9,33 95\%CI=2,8530,6), kecukupan lemak (OR=6 95\%CI=1,48-24,3), kecukupan protein $(O R=3,8295 \% C I=1,15-12,71)$, dan status gizi ibu $(O R=4,9795 \% C I=1,39-17,82)$. Tingkat aktivitas fisik $(O R=0,8895 \% C I=0,32-2,4)$, status gizi ayah $($ OR $=1$ $95 \% C I=0,34-2,92)$, dan tingkat pendapatan perkapita $(O R=3,595 \% C I=0,65-2,67)$ bukan merupakan faktor risiko kejadian overweight pada anak stunting.

Kesimpulan : Kecukupan energi, kecukupan lemak, kecukupan protein, dan status gizi ibu merupakan faktor risiko kejadian overweight pada anak stunting.
\end{abstract}

Kata kunci: kecukupan energi; kecukupan lemak; kecukupan protein; status gizi orang tua; overweight; stunting

${ }^{*}$ Penulis Penanggungjawab 


\section{PENDAHULUAN}

Stunting merupakan masalah utama di negara-negara berkembang termasuk Indonesia. Stunting merupakan gangguan pertumbuhan linear akibat kekurangan gizi kronis, kondisi ini ditandai dengan tinggi badan kurang dari normal berdasarkan usia dan jenis kelamin ${ }^{1}$. Hasil Riskesdas tahun 2010 menunjukkan bahwa di Jawa Tengah terdapat $14,9 \%$ kategori sangat pendek dan $19,2 \%$ kategori pendek untuk anak usia 6-12 tahun menurut tinggai badan berdasarkan umur $(\mathrm{TB} / \mathrm{U}){ }^{2}$

Berdasarkan teori Barker, gangguan pertumbuhan juga mencerminkan berkurangnya jumlah dan kualitas sel serta jaringan organ internal anak, diantaranya berupa gangguan sistem endokrin $^{3}$. Gangguan sintem endokrin tersebut mempengaruhi proses oksidasi lemak sehingga berakibat pada penumpukan jaringan adiposa ${ }^{4}$. Hasil penelitian di Amerika Selatan terhadap anak kurang gizi juga menunjukkan bukti bahwa terdapat simpanan lemak yang lebih besar dibandingkan simpanan protein ketika anak-anak tersebut mengalami perbaikan gizi ${ }^{5}$. Penelitian di Rusia pada anak usia 3-9 tahun menunjukkan bahwa terdapat $45,1 \%$ anak stunting disertai overweight dengan risk rasio sebesar 1,7-7,8 kali ${ }^{6}$. Teori Barker juga menyebutkan bahwa overweight pada anak menimbulkan risiko penyakit metabolik pada saat ini dan masa dewasa ${ }^{3}$.

Aspek kuantitas maupun komposisi asupan juga berperan dalam meningkatkan risiko kejadian overweight. Peningkatan berat badan pada anakanak dipengaruhi oleh asupan tinggi energi dan lemak ${ }^{7}$. Peningkatan pendapatan, urbanisasi, iklan dan outlet makanan siap saji berdampak pada peningkatan konsumsi daging, produk susu, dan makanan tinggi gula serta junk foods ${ }^{8}$. Kelebihan asupan juga akan disimpan oleh tubuh berupa simpanan lemak sebesar $60-80 \%$. Hasil penelitian di Inggris menunjukkan bahwa anak sekolah mengonsumsi lebih dari $90 \%$ energi dan $75 \%$ lemak dari rekomendasi asupan harian (Recomended Daily Allowance/RDA) ${ }^{9}$.

Aktivitas fisik memiliki peran penting dalam penurunan berat badan karena melibatkan peningkatan pengeluaran energi sebesar $20-50 \%{ }^{10}$. Sebuah penelitian di Jamaika menunjukkan bahwa pengeluaran energi anak stunting lebih rendah daripada anak normal. Hal ini merupakan bentuk kompensasi tubuh terhadap asupan energi yang rendah sehingga meningkatkan risiko anak stunting untuk menjadi overweight ketika aktivitas fisik menurun ${ }^{11}$.
Faktor genetik juga berpengaruh pada kejadian overweight. Penelitian di Inggris menunjukkan apabila kedua orang tua overweight, maka anak pun berpotensi 10 kali mengalami overweight $^{12}$. Ayah dengan IMT $\geq 30$ memberikan risiko 2,54 kali kepada anak untuk menjadi overweight, sedangkan ibu dengan IMT $\geq 30$ meningkatkan risiko sebesar 4,25 $\mathrm{kali}^{12}$. Ayah overweight juga cenderung memberikan contoh perilaku mengonsumsi makanan yang kurang sehat dan gaya hidup sedentari ${ }^{13}$. Keluarga dengan orang tua overweight juga cenderung mengonsumsi makanan dengan persentase lemak yang lebih tinggi ${ }^{7}$.

Pendapatan dan status sosial ekonomi juga berkontribusi pada peningkatan indeks massa tubuh (IMT) pada negara-negara berkembang. Pendapatan yang tinggi dihubungkan dengan peningkatan konsumsi makanan serta keragaman pemilihan jenis makanan ${ }^{8}$. Sejak tahun 2007-2011, Indonesia telah menunjukkan penurunan tingkat kemiskinan yang signifikan dari $16,6 \%$ menjadi $12,5 \%{ }^{14}$. Pertumbuhan ekonomi yang cepat dan perubahan demografi yang terjadi pada negaranegara berkembang membawa dampak perkembangan terhadap transportasi dan teknologi. Hal ini juga membawa dampak penurunan aktivitas fisik sehingga pengeluaran energi juga semakin berkurang ${ }^{10}$.

Anak-anak cenderung mengalami perubahan pola makan dan aktivitas fisik pada saat memasuki usia sekolah. Berdasarkan penelitian pendahuluan (skrining) yang dilakukan di empat sekolah dasar di Semarang Timur ditemukan 14,49\% anak overweight dan $47,5 \%$ anak stunting dengan jumlah 20,94\% mild stunting, 19,02\% moderate stunting, dan $7,5 \%$ severe stunting . Jumlah tersebut tidak berbeda jauh dengan persentase jumlah anak stunting berdasarkan hasil Riskesdas Jawa Tengah tahun 2010.

\section{METODE}

Penelitian ini dilaksanakan di 4 SD Negeri Desa Kemijen yaitu SDN Kemijen 1, SDN Kemijen 2, SDN Kemijen 3, dan SDN Kemijen 4. Pelaksanaan penelitian pada bulan Juli-Oktober 2013. Penelitian diawali dengan skrining 1146 anak pada keempat SD tersebut kemudian dibagi 30 kelompok kasus (overweight) dan 30 kelompok kontrol (tidak overweight) melalui metode purposive sampling. Jenis penelitian ini menggunakan desain case control study dengan matching usia, jenis kelamin, serta derajat stunting. 
Subjek penelitian adalah anak SD kelas 1-6 dengan rentang usia 6-13 tahun.

Kriteria Inklusi untuk kelompok kasus penelitian ini yaitu anak SD kelas 1-6, Z-skor $\mathrm{TB} / \mathrm{U} \leq-1 \mathrm{SD}, \mathrm{Z}$-skor IMT/U $\geq 1 \mathrm{SD}$, dan bersedia menjadi subjek penelitian dengan mengisi informed consent. Kriteria Inklusi untuk kelompok kontrol penelitian ini yaitu anak SD kelas 1-6, Zskor $\mathrm{TB} / \mathrm{U} \leq-1 \mathrm{SD}$, Z-skor IMT/U $<1 \mathrm{SD}$, dan bersedia menjadi subjek penelitian dengan mengisi informed consent. Kriteria eksklusi penelitian ini yaitu sakit saat pengambilan data serta mengundurkan diri menjadi subjek penelitian atau pindah sekolah.

Variabel dependent dalam penelitian ini adalah kejadian overweight pada anak stunting dan variabel independent adalah kecukupan energi, kecukupan lemak, kecukupan protein, aktivitas fisik, pendapatan perkapita keluarga, status gizi ayah, dan status gizi ibu. Kategori stunting dibagi menjadi 3 yaitu mild stunting $(-1 \mathrm{SD} \geq \mathrm{z}$-skor $\mathrm{TB} / \mathrm{U}>-2 \mathrm{SD})$, moderate stunting $(-2 \mathrm{SD} \geq \mathrm{z}$-skor $\mathrm{TB} / \mathrm{U}>-3 \mathrm{SD}$ ), dan severe stunting (z-skor $\mathrm{TB} / \mathrm{U}$ $\geq-3 \mathrm{SD}$ ). Kategori overweight $\mathrm{z}$-skor IMT/U $\geq 1$ $\mathrm{SD}$ dan normal/kurang yaitu z-skor IMT/U $<1 \mathrm{SD}$. Pengolahan dan analisa data z-skor TB/U dan IMT/U menggunakan software WHO Anthroplus.

Data asupan energi dan protein diperoleh melalui kuesioner dengan wawancara FFQ (Food Frequency Questionaire) semi kuantitatif. Kategori kecukupan energi tinggi yaitu > $100 \%$ dan normal/kurang $\leq 100 \%$ kecukupan energi harian. Kategori kecukupan lemak dan protein tinggi yaitu $>100 \%$ dan normal/kurang jika $\leq 100 \%$ kecukupan lemak dan protein harian.
Aktivitas fisik yaitu durasi melakukan kegiatan sehari-hari selama 7 hari dihitung berdasarkan menit, melalui wawancara dengan pengisian kuesioner modifikasi Physical Activity Questionaire Children (PAQ-C). ${ }^{15}$ Kategori aktivitas fisik rendah apabila melakukan kegiatan < 45 menit/hari dengan jenis aktivitas fisik sedang sampai dengan berat dan tinggi jika melakukan kegiatan $\geq 45$ menit/hari dengan jenis aktivitas fisik sedang sampai dengan berat ${ }^{16}$.

Pendapatan perkapita keluarga diperoleh melalui kuesioner dengan wawancara kepada orang tua. Pendapatan perkapita keluarga dikategorikan berdasarkan garis kemiskinan menurut standar Badan Pembangunan Nasional Tahun 2012 untuk Kota Semarang. Kategori pendapatan perkapita rendah apabila pendapatan perkapita < Rp 245817 dan kategori pendapatan tinggi apabila pendapatan perkapita $>\operatorname{Rp} 245817^{17}$. Penentuan IMT diawali dengan pengukuran antropometri berupa tinggi badan dan berat badan ayah serta ibu. IMT kemudian dikategorikan menjadi normal/kurang apabila IMT $<23$ dan lebih apabila IMT $>23^{2}$.

Analisis data yang digunakan adalah Chi Square dengan interval kepercayaan 95\%. Uji Fischer Exact digunakan jika uji Chi Square tidak memenuhi syarat yaitu apabila sel yang memiliki nilai expected kurang dari 5 berjumlah $>20 \%$. Penentuan besar risiko diperoleh menggunakan odds ratio.

\section{HASIL PENELITIAN \\ Karakteristik subjek penelitian}

Tabel 1. Sebaran data hasil skrining

\begin{tabular}{lcc}
\hline Indikator & $\mathbf{n}$ & $\%$ \\
\hline TB/U & & \\
$\quad$ Normal & 496 & $52,53 \%$ \\
$\quad$ Mild stunting & 240 & $20,94 \%$ \\
$\quad$ Moderate stunting & 218 & $19,02 \%$ \\
$\quad$ Severe Stunting & 86 & $7,50 \%$ \\
IMT/U & & \\
$\quad$ Underweight & 443 & $38,66 \%$ \\
$\quad$ Normal & 439 & $38,31 \%$ \\
Overweight & 166 & $14,49 \%$ \\
Obese & 98 & $8,55 \%$ \\
\hline
\end{tabular}

Skrining awal dilakukan pada 1146 anak dari 4 SD Negeri di Kelurahan Kemijen dengan hasil 264 anak mengalami overweight dan 544 anak dengan stunting, serta 33 anak stunting disertai dengan overweight (Tabel 1).

Subjek penelitian ini memiliki rentang usia 613 tahun dengan persentase jenis kelamin laki-laki, 
derajat moderate stunting, dan usia 6-9 tahun yang lebih banyak (Tabel 2).

Tabel 2. Karakteristik sampel

\begin{tabular}{lcccc}
\hline \multirow{2}{*}{ Variabel } & \multicolumn{2}{c}{ Kasus } & $\mathrm{n}$ & Kontrol \\
\cline { 2 - 5 } & $\mathrm{n}$ & $\%$ & & \\
\hline Jenis Kelamin & & $60 \%$ & 18 & $60 \%$ \\
$\quad$ Laki-laki & 18 & $40 \%$ & 12 & $40 \%$ \\
$\quad \begin{array}{l}\text { Perempuan } \\
\text { Usia }\end{array}$ & 12 & & & \\
$\quad 6-9$ tahun & 20 & $66.7 \%$ & 20 & $66.7 \%$ \\
$\quad \begin{array}{l}10-13 \text { tahun } \\
\text { Derajat stunting }\end{array}$ & 10 & $33.3 \%$ & 10 & $33.3 \%$ \\
$\quad \begin{array}{l}\text { Mild stunting } \\
\text { Moderate }\end{array}$ & 13 & $43,33 \%$ & 13 & $43,33 \%$ \\
stunting & 17 & $56,67 \%$ & 17 & $56,67 \%$ \\
\hline
\end{tabular}

Tabel 3 dapat diketahui rerata Z-skor TB/U kelompok kasus adalah $-1,82$ SD dan $-2,17$ SD pada kelompok kontrol. Rerata Z-skor IMT/U pada kelompok kasus adalah 1,68 SD sedangkan pada kelompok kontrol -1,12 SD.

Tabel 3. Usia dan status gizi subjek

\begin{tabular}{lcccccc}
\hline \multirow{2}{*}{ Variabel } & \multicolumn{3}{c}{ Kasus } & $\mathrm{n}=30$ & & \multicolumn{3}{c}{ Kontrol } \\
\cline { 2 - 7 } & rerata \pm SD & Minimal & Maksimal & rerata \pm SD & Minimal & Maksimal \\
\hline $\begin{array}{l}\text { Umur } \\
\begin{array}{l}\text { Z-skor IMT/U } \\
\text { (SD) }\end{array}\end{array}$ & $9,24 \pm 1,69$ & 6,51 & 13,1 & $9,19 \pm 1,79$ & 6,54 & 13,53 \\
$\begin{array}{l}\text { Z-skor TB/U } \\
\text { (SD) }\end{array}$ & $1,68 \pm 0,60$ & 1,01 & 3,12 & $-1,12 \pm 0,89$ & $-2,63$ & 0,82 \\
\hline
\end{tabular}

Kecukupan energi, kecukupan lemak, kasus memiliki median sebesar $108 \%$ sedangkan kecukupan protein, dan tingkat aktivitas fisik untuk kelompok kontrol 97\%. Nilai median untuk

Kecukupan energi pada kelompok kasus kecukupan lemak pada kelompok kasus adalah cenderung lebih jika dibandingkan dengan 148,5\%, sedangkan pada kelompok kontrol sebesar kelompok kontrol. Kecukupan lemak dan 121,26\%. Kecukupan protein, kelompok kasus kecukupan protein tergolong lebih pada kelompok memiliki median $122 \%$ sedangkan kelompok kasus maupun kelompok kontrol. Tabel 4 kontrol memiliki median 111,5\%. menunjukkan kecukupan energi pada kelompok

Tabel 4. Persen asupan energi, protein dan aktivitas fisik berdasarkan kelompok kasus dan kontrol

\begin{tabular}{lcccccc}
\hline \multirow{2}{*}{ Variabel } & \multicolumn{2}{c}{ Kasus } & \multicolumn{3}{c}{ Kontrol } \\
\cline { 2 - 6 } & Median & Minimal & Maksimal & Median & Minimal & Maksimal \\
\hline Kecukupan energi (\%) & 108 & 79 & 171 & 97 & 61 & 158 \\
Kecukupan lemak (\%) & 148,5 & 91 & 228 & 121,26 & 87 & 185 \\
Kecukupan protein (\%) & 122 & 78 & 197 & 111,5 & 60 & 164 \\
Aktivitas fisik (menit) & 42,86 & 8,47 & 154,29 & 47,86 & 17,14 & 145,71 \\
\hline
\end{tabular}

\section{Karakteristik keluarga subjek penelitian}

Status gizi ayah maupun ibu pada kelompok kasus maupun kontrol sebagian besar termasuk dalam kategori overweight. Sebagian besar kedua orang tua subjek pada kelompok kasus sebanyak 93,3\% dan pada kelompok kontrol sebanyak $80 \%$ dikategorikan sebagai tingkat pendapatan tinggi . Tabel 5 menunjukkan rerata pendapatan perkapita pada kelompok kasus sedikit lebih tinggi Rp. 454.000 daripada kelompok kontrol dengan pendapatan sebesar Rp 378.000. 
Tabel 5. Distribusi pendapatan perkapita keluarga, IMT ayah, dan IMT Ibu

\begin{tabular}{lllllll}
\hline \multirow{2}{*}{ Variabel } & \multicolumn{3}{c}{ Kasus } & \multicolumn{3}{c}{ Kontrol } \\
\cline { 2 - 6 } & Rerata \pm SD & Minimum & Maksimum & Rerata \pm SD & Minimum & Maksimum \\
\hline $\begin{array}{l}\text { Pendapatan } \\
\text { perkapita }\end{array}$ & $454000 \pm 174$ & & & $378000 \pm 15$ & \\
(Rp) & 672,22 & 128571 & 833333 & 9492,69 & 160000 & 800000 \\
$\begin{array}{l}\text { IMT Ayah } \\
\left(\mathrm{kg} / \mathrm{m}^{2}\right)\end{array}$ & $25,62 \pm 3,90$ & 19,55 & 33,08 & $24,13 \pm 2,35$ & 20,49 & 28,01 \\
$\begin{array}{l}\text { IMT Ibu } \\
\left(\mathrm{kg} / \mathrm{m}^{2}\right)\end{array}$ & $27,25 \pm 3,54$ & 18,98 & 31,77 & $23,88 \pm 3,70$ & 17,67 & 29,89 \\
\hline
\end{tabular}

Faktor Risiko Kejadian Overweight pada Anak Stuting

Tabel 6 menunjukkan yang merupakan faktor risiko kejadian overweight pada anak stunting adalah kecukupan energi $(\mathrm{OR}=9,3395 \% \mathrm{CI}=2,85$ 30,6), kecukupan lemak (OR=6 95\%CI=1,48-
$24,3)$, kecukupan protein $(\mathrm{OR}=3,8295 \% \mathrm{CI}=1,15$ $12,71)$, dan status gizi ibu $(\mathrm{OR}=4,9795 \% \mathrm{CI}=1,39$ 17,82). Tingkat aktivitas fisik $(\mathrm{OR}=0,8895 \% \mathrm{CI}=$ $0,32-2,4)$, status gizi ayah $(\mathrm{OR}=195 \% \mathrm{CI}=0,34-$ $2,92)$, dan tingkat pendapatan perkapita $(\mathrm{OR}=3,5$ $95 \% \mathrm{CI}=0,65-2,67)$ bukan merupakan faktor risiko.

Tabel 6. Analisis bivariat faktor risiko overweight pada anak stunting

\begin{tabular}{|c|c|c|c|c|c|c|c|}
\hline \multirow{2}{*}{ Faktor Risiko } & \multicolumn{2}{|c|}{ Kasus } & \multicolumn{2}{|c|}{ Kontrol } & \multirow[b]{2}{*}{$\mathrm{p}$} & \multirow{2}{*}{ OR } & \multirow{2}{*}{$95 \%$ CI } \\
\hline & $\mathrm{n}$ & $\%$ & $\mathrm{n}$ & $\%$ & & & \\
\hline Kecukupan Energi & 6 & $20 \%$ & 21 & $70 \%$ & & & \\
\hline $\begin{array}{l}\text { Kurang/ normal } \\
\text { Lebih }\end{array}$ & 24 & $80 \%$ & 9 & $30 \%$ & 0,00 & 9,33 & $2,85-30,6$ \\
\hline Kecukupan Lemak & 3 & $10 \%$ & 12 & $40 \%$ & & & \\
\hline $\begin{array}{l}\text { Kurang/ normal } \\
\text { Lebih }\end{array}$ & 27 & $90 \%$ & 18 & $60 \%$ & 0,01 & 6 & $1,48-24,3$ \\
\hline Kecukupan Protein & 5 & $16,7 \%$ & 12 & $40 \%$ & & & \\
\hline $\begin{array}{l}\text { Kurang/ normal } \\
\text { Lebih }\end{array}$ & 25 & $83,3 \%$ & 18 & $60 \%$ & 0,047 & 3,82 & $1,15-12,71$ \\
\hline Aktivitas fisik & & & & & & & \\
\hline $\begin{array}{l}\text { Tidak aktif }(<45 \text { menit }) \\
\text { Aktif }(\geq 45 \text { menit })\end{array}$ & $\begin{array}{l}14 \\
16\end{array}$ & $\begin{array}{l}46,7 \% \\
53,3 \%\end{array}$ & $\begin{array}{l}15 \\
15\end{array}$ & $\begin{array}{l}30 \% \\
30 \%\end{array}$ & 0,796 & 0,88 & $0,32-2,4$ \\
\hline Status gizi ayah & & & & & & & \\
\hline $\begin{array}{l}\text { Kurang/normal } \\
\text { Overweight }\end{array}$ & $\begin{array}{l}10 \\
20\end{array}$ & $\begin{array}{l}33 \% \\
67 \%\end{array}$ & $\begin{array}{l}10 \\
20\end{array}$ & $\begin{array}{l}63,3 \% \\
36,7 \%\end{array}$ & 1 & 1 & $0,34-2,92$ \\
\hline Status gizi ibu & & & & & & & \\
\hline $\begin{array}{l}\text { Kurang/normal } \\
\text { Overweight }\end{array}$ & $\begin{array}{c}4 \\
26\end{array}$ & $\begin{array}{l}13,3 \% \\
86,7 \%\end{array}$ & $\begin{array}{l}13 \\
17\end{array}$ & $\begin{array}{l}43,3 \% \\
53,3 \%\end{array}$ & 0,01 & 4,97 & $1,39-17,82$ \\
\hline Pendapatan/kapita & & & & & & & \\
\hline $\begin{array}{l}\text { Rendah } \\
\text { Tinggi }\end{array}$ & $\begin{array}{c}2 \\
28\end{array}$ & $\begin{array}{l}6,7 \% \\
93,3 \%\end{array}$ & $\begin{array}{c}6 \\
24\end{array}$ & $\begin{array}{l}20 \% \\
80 \%\end{array}$ & 0,127 & 3,5 & $0,65-2,67$ \\
\hline
\end{tabular}

\section{PEMBAHASAN}

Hasil penelitian ini menunjukkan bahwa pada rentang usia 6-13 tahun, lebih banyak anak stunting yang mengalami overweight berada pada usia 6-9 tahun. Hal ini dikarenakan pada usia 6-9 tahun anak-anak mengalami fase lonjakan peningkatan lemak setelah masa minimal penyimpanan lemak. Anak-anak mengalami peningkatan IMT secara cepat pada fase tahun pertama kehidupan, kemudian menurun hingga puncaknya pada usia 6-7 tahun. Fase dimana anak memiliki lean body mass paling tinggi dan IMT paling rendah disebut masa adiposity rebound. Selajutnya anak akan mengalami peningkatan simpanan lemak (rebound) dan peningkatan IMT hingga masa pubertas. ${ }^{18}$ 
Jenis kelamin laki-laki juga diketahui lebih banyak overweight dibanding perempuan pada rasras tertentu, termasuk Asia. Hasil penelitian ini sama dengan penelitian sebelumnya yang dilakukan di Indonesia. ${ }^{10}$ Anak laki-laki cenderung mengasup lebih banyak makanan, sedangkan anak perempuan cenderung membatasi asupan karena pengaruh body image. ${ }^{10}$ Teori Barker juga menyebutkan bahwa janin laki-laki memiliki kemampuan memperluas plasenta ketika mereka dalam kondisi kurang gizi sehingga anak dapat berisiko mengalami overweight ketika dewasa. ${ }^{3}$

Penelitian ini menununjukkan bahwa kecukupan energi, kecukupan lemak, dan kecukupan protein merupakan faktor risiko kejadian overweight pada anak stunting. Hasil food frequency semi-quantitative menunjukkan bahwa kuantitas jenis makanan kelompok kasus lebih besar daripada kelompok kontrol. Kelompok kasus mengasup 3-4 ukuran rumah tangga (URT) sumber lauk hewani dengan rerata $1 \mathrm{x} /$ hari serta makanan jajanan dengan rerata 2x/minggu. Kelompok kontrol mengasup 1-2 URT sumber lauk hewani dengan rerata $1 \mathrm{x} /$ hari serta makanan jajanan 1x/bulan Penelitian di Brazil sebelumnya menyebutkan bahwa anak-anak stunting kemungkinan memiliki kerusakan regulasi energi. Berdasarkan teori regulasi energi, deplesi simpanan karbohidrat merupakan sinyal kelaparan. Anak stunting memiliki kecenderungan mudah lapar karena adanya peningkatan oksidasi karbohidrat yang mengarah pada deplesi penyimpanan karbohidrat secara cepat ${ }^{19}$. Penelitian sebelumnya di Brazil anak stunting yang mengalami overweight usia 8-11 tahun diketahui mengasup lebih banyak energi $(\bar{x}=1920$ Kal $)$ dibandingkan dengan anak normal $(\overline{\mathrm{x}}=1850,88$ Kal). ${ }^{19}$

Secara teoritis, konsumsi makanan tinggi lemak akan meningkatkan kerentanan anak stunting terhadap kelaparan dan kelebihan makan ${ }^{19}$. Anak stunting akan memproduksi lebih banyak simpanan lemak dibandingkan dengan anak normal ${ }^{6}$. Asupan energi yang rendah selama pertumbuhan diketahui menurunkan level faktor pertumbuhan 1 seperti insulin (IGF1) dan meningkatkan rasio kortisol terhadap insulin. Level IGF1 yang rendah dapat merusak lipolisis, sebagai konsekuensinya, peningkatan lemak tubuh mungkin terjadi dengan adanya makanan tinggi lemak karena berkurangnya kemampuan untuk mengoksidasi lemak dari makanan ${ }^{19}$. Penelitian sebelumnya di Brazil anak stunting yang mengalami overweight usia 8-11 tahun diketahui mengasup lebih banyak lemak ( $\overline{\mathrm{x}}=47,85$ gr $)$ dibandingkan dengan anak normal $(\overline{\mathrm{x}}=47,14 \mathrm{gr}) .{ }^{19}$

Kecukupan protein berhubungan dengan kejadian overweight pada anak stunting dan terbukti sebagai faktor risiko dalam penelitian ini. Kelebihan asupan dalam tubuh termasuk kelebihan asupan protein akan disimpan berupa lemak. Peningkatan rasio protein juga dapat mempengaruhi IGF1 dimana berefek pada peningkatan sel di seluruh jaringan termasuk jaringan adiposa. ${ }^{20}$ Asupan energi yang rendah selama pertumbuhan diketahui menurunkan level faktor pertumbuhan 1 seperti insulin (IGF1) sehingga asupan protein yang tinggi pada anak stunting kurang berpengaruh pada pertumbuhan tinggi badan. ${ }^{19}$ Penelitian sebelumnya di Brazil menunjukkan bahwa anak stunting yang mengalami overweight usia 8-11 tahun diketahui mengasup lebih banyak protein $(\overline{\mathrm{x}}=46,27$ gr $)$ dibandingkan dengan anak normal $(\overline{\mathrm{x}}=50,07 \mathrm{gr}){ }^{19}$ Level IGF1 yang rendah dan adanya kerusakan oksidasi lemak mengindikasikan bahwa berat badan anak stunting harus senantiasa dipertahankan sesuai berat badan ideal untuk mengurangi terjadinya overweight.

Aktivitas fisik diketahui membantu menurunkan berat badan dengan meningkatkan pengeluaran energi sebesar 20-50\%. ${ }^{10}$ Keadaan overweight banyak dihubungkan dengan gaya hidup sedentari dan tingkat aktivitas fisik rendah. Hasil penelitian ini sama dengan penelitian di Kamerun, disebutkan bahwa anak stunting baik normal maupun dengan overweight keduanya cenderung memiliki aktivitas fisik yang kurang terutama pada anak perempuan ${ }^{11}$. Penelitian terdahulu di Kamerun menunjukkan anak stunting memiliki simpanan energi yang lebih rendah dibanding dengan anak normal, sehingga aktivitas fisik yang rendah merupakan salah satu bentuk adaptasi tubuh terhadap kekurangan energi tersebut ${ }^{11}$. Ketersedian energi yang lebih banyak juga menjadi kemungkinan alasan mengapa beberapa anak stunting disertai overweight menjadi lebih aktif beraktivitas fisik. ${ }^{11}$

Status gizi ayah dalam penelitian ini bukan merupakan faktor risiko kejadian overweight pada anak stunting. Hal ini berbeda dengan penelitian sebelumnya di Inggris bahwa ayah dengan IMT $\geq$ 30 memberikan risiko 2,54 kali kepada anak untuk menjadi overweight. ${ }^{12}$ Perbedaan ini dikarenakan dalam penelitian ini tidak terdapat data apakah ayah mengalami overweight murni akibat paparan gen atau diikuti pengaruh lingkungan. Penelitian sebelumnya di Inggris juga menyebutkan bahwa 
ayah merupakan sosok paling berpengaruh dalam memberikan contoh kebiasaan dan gaya hidup. Ayah dengan status gizi overweight memiliki kebiasaan dan gaya hidup yang kurang sehat selanjutnya menjadi contoh bagi keluarganya. ${ }^{13}$ Penelitian ini menunjukkan bahwa sebagian besar ayah bekerja sehingga kemungkinan ayah menghabiskan lebih banyak waktu di luar rumah.

Status gizi ibu merupakan faktor risiko kejadian overweight pada anak stunting. Hal ini sesuai dengan penelitian di Inggris bahwa ibu dengan overweight menurunkan risiko sebesar 4,25 kali kepada anaknya. ${ }^{12}$ IMT ibu memiliki efek genetik yang lebih kuat daripada ayah terhadap kejadian overweight pada keturunannya. Simpanan lemak yang lebih besar dalam tubuh ibu selama masa kehamilan mengarah kepada perubahan metabolisme, kontrol nafsu makan dan fungsi sistem endokrin janin sehingga berakibat pada peningkatan risiko overweight pada masa kanakkanak serta dewasa ${ }^{3}$.

Pendapatan dihubungkan dengan kemampuan daya beli dan jenis makanan yang dikonsumsi yang dipengaruhi oleh pendapatan keluarga. Seseorang dengan pendapatan lebih tinggi mampu memilih makanan yang lebih bervariasi meskipun dalam sisi nilai gizi terkadang tidak jauh berbeda dengan keluarga yang memiliki pendapatan kurang ${ }^{7}$. Pendapatan perkapita bukan merupakan faktor risiko dalam penelitian ini, berbeda dengan penelitian yang dilakukan oleh Popkin. ${ }^{6}$ Pendapatan perkapitan keluarga pada kelompok kasus maupun kelompok kontrol tergolong tinggi. Pendapatan perkapita yang lebih tinggi membuat keluarga kelompok kasus tersebut mampu untuk mengonsumsi jenis makanan dengan kuantitas lebih banyak. Kelompok kontrol mengonsumsi jenis makanan yang lebih rendah kuantitasnya daripada kelompok kasus, sehingga kemungkinan pendapatan tersebut sebagian besar digunakan untuk mencukupi kebutuhan diluar kebutuhan pangan.

\section{SIMPULAN}

Kecukupan energi $(\mathrm{OR}=9,3395 \% \mathrm{CI}=2,85$ $30,6)$, kecukupan lemak $(\mathrm{OR}=695 \% \mathrm{CI}=1,48$ $24,3)$, kecukupan protein $(\mathrm{OR}=3,8295 \% \mathrm{CI}=$ $1,15-12,71)$, dan status gizi ibu $(\mathrm{OR}=4,9795 \%$ $\mathrm{CI}=1,39-17,82)$.merupakan faktor risiko kejadian overweight pada anak stunting usia sekolah dasar.

\section{SARAN}

Bagi sekolah, dapat memberikan himbauan kepada siswa-siswi untuk memantau berat badan dan tinggi badan anak sekolah agar mengurangi kejadian overweight khususnya pada anak stunting serta memotivasi anak untuk melakukan aktivitas fisik melalui pelajaran olahraga.

Bagi orang tua subjek, juga disarankan untuk memantau berat dan tinggi badan anak sejak dini secara rutin. Orang tua sebaiknya juga memperhatikan jenis makanan yang dikonsumsi oleh keluarga dengan membatasi konsumsi makanan tinggi energi, tinggi lemak, dan tinggi protein serta mengajarkan pola hidup sehat kepada anak.

\section{DAFTAR PUSTAKA}

1. Eugene M. Lewit, Nancy Kerrebrock. PopulationBased Growth Stunting [serial online]. The Future of Children CHILDREN AND POVERTY Vol. 7 • No. 2 - Summer/Fall. 1997 [dikutip 6 Mei 2013]. Diunduh dari: http://www.princeton.edu/futureofchildren/publicat ions/docs/07_02_Indicators.pdf

2. Badan Penelitian dan Pengembangan Kesehatan kementrian Kesehatan RI. Riset Kesehatan Dasar 2010: Laporan Nasional [serial online]. 2010. dikutip 8 Mei 2013] Diunduh dari: http://www.litbang.depkes.go.id/sites/download/bu $\mathrm{ku}$ _laporan/lapnas_riskesdas2010/Laporan_riskesd as_2010.pdf

3. C Nicholas Hales, David J P Barker. The Thrifty Phenotype Hypothesis. British Medical Bulletin 2001; 60: 5-20

4. Hoffman, D. J., Sawaya, A. L., Verreschi, I., Tucker, K. L., Roberts, S. B. Why Are Nutritionally Stunted Children At Increased Risk Of Obesity? Studies Of Metabolic Rate And Fat Oxidation In Shantytown Children From São Paulo, Brazil. 2000. American Journal Of Clinical Nutrition, 72:702-707

5. Ana Lydia Sawaya. Susan Roberta. Stunting and future risk of obesity: principal physiological mechanisms. 2003. Cad. Saúde Pública, Rio de Janeiro, 19(Sup. 1):S21-S28

6. Barry M. Popkin, Marie K. Richards, Carlos A. Mohtiero. Stunting Is Associated With Overweight In Children Of Four Nations That Are Undergoing The Nutrition Transition. J. Nutr.-1996-Popkin3009-16

7. C Maffeis, G Talamini, L Tato. Influence Of Diet, Physical Activity And Parents' Obesity On Children's Adiposity: A Four-Year Longitudinal Study. International Journal of Obesity (1998) 22, $758 \pm 764$

8. Cornelia Roemling, Matin Qaim. Obesity Trends And Determinants In Indonesia. 2012. Elsevier. doi:10.1016/j.appet.2012.02.053

9. Chris Holden. Anita MacDonald. Nutrition and Child Health. 2000. London : Harcourt Publisher 
10. Ratu Ayu Dewi Sartika. Faktor Risiko Obesitas Pada Anak 5-15 Tahun Di Indonesia. [serial online]. Makara, Kesehatan, Vol. 15, No. 1, Juni 2011: 37-43. [dikutip 29 April 2013] Diunduh dari:

http://journal.ui.ac.id/index.php/health/article/dow nload/796/758

11. Said-Mohamed R, Bernard JY, Ndzana A-C, Pasquet P (2012) Is Overweight in Stunted Preschool Children in Cameroon Related to Reductions in FatOxidation, Resting Energy Expenditure and Physical Activity? PLoS ONE 7(6): e39007. doi:10.1371/journal.pone.0039007

12. John J Reilly, Julie Armstrong, Ahmad R Dorosty, et al. Early life risk factors for obesity in childhood: cohort study. BMJ, doi:10.1136/bmj.38470.670903.E0 (published 20 May 2005)

13. Brophy S, Rees A, Knox G, Baker J, Thomas NE (2012) Child Fitness and Father's BMI Are Important Factors in Childhood Obesity: A School Based Cross-Sectional Study. PLoS ONE 7(5): e36597. doi:10.1371/journal.pone.0036597

14. UNICEF Indonesia. Issue Briefs : Maternal and Child Nutrition. 2012. Jakarta. [dikutip 20 Juli 2013]. Diunduh dari: http://www.unicef.org/indonesia/A6_E_Issue_Brief_Child_Nutrition_REV2.pdf

15. Kent C. Kowalski. Peter R. E. Crocker. Rachel M. Donen. The Physical Activity Questionnaire for Older Children (PAQ-C) and Adolescents (PAQA) Manual. 2004. Canada : Colloge of Kinesiology, University of Saskatchewan

16. Lambert NJF, Aggoun Yacine, Marchand LM, Martin XE, Herrmann FR, Beghetti Maurice. Physical Activity Reduces Systemic Blood Pressure and Improves Early Markers of Atherosclerosis in Pre-Pubertal Obese Children. Journal of the American College of Cardiology 2009; 54:25.

17. BPS. Laporan Bulanan Data Sosial Ekonomi. Edisi 34 Maret 2013. Jakarta

18. MF Rolland-Cachera, M Deheeger, M Maillot, F Bellisle. Early Adiposity Rebound: Causes And Consequences For Obesity In Children And Adults. International Journal of Obesity (2006) 30, S11-S17. doi:10.1038/sj.ijo.0803514

19. Daniel J. Hoffman, Susan B. Roberts, Ieda Verresch, et al. Regulation of Energy Intake May Be Impaired in Nutritionally Stunted Children from the Shantytowns of Sao Paulo, Brazil. J. Nutr. 130:2265-2270, 2000.

20. Jana Parizkova, Andrew Hills. Childhood Obesity Prevention and Treatment, Second Edition crc press 2004 US

21. Agneta Hornell, Hanna Lagstrom, Britt Lande, Inga Thorsdottir. Protein Intake From 0 To 18 Years Of Age And Its Relation To Health: A Systematic Literature Review For The 5th Nordic
Nutrition Recommendations. Food \& Nutrition Research 2013. 57: 21083 http://dx.doi.org/10.3402/fnr.v57i0.21083

22. Perez-Pastor EM, Metcalf BS, Hosking J, Jeffery A, Voss L, et al. Assortative weight gain in mother-daughter and father-son pairs: an emerging source of childhood obesity. Longitudinal study of trios (EarlyBird 43). 2009. Int J Obes (Lond) 33(7): 727-35.

23. Von $\mathrm{T}$ Nguyen, $\mathrm{D}$ Enette Larson, Rachel K Johnson, Michael 1 Goran. Fat intake and adiposity in children of lean and obese parents. Am.J.Cli.Nutr 1996;63:50713.

24. Jaana Laitinen, Chris Power, and Marjo-Riitta Järvelin. Family Social Class, Maternal Body Mass Index, Childhood Body Mass Index, And Age At Menarche As Predictors Of Adult Obesity. Am J Clin Nutr 2001;74:287-94 